\title{
Ectomycorrhizal Fungi Associated with Pinus densiflora Seedlings under Flooding Stress
}

\author{
Yoonhee Cho ${ }^{1}$, Shinnam Yoo ${ }^{1}$, Myung Soo Park ${ }^{1}$, Ji Seon Kim ${ }^{1}$, Chang Sun Kim ${ }^{2}$ and Young Woon Lim ${ }^{1, *(D)}$ \\ 1 Institute of Microbiology, School of Biological Sciences, Seoul National University, Seoul 08826, Korea; \\ yuniq@snu.ac.kr (Y.C.); dbqnchqkq93@snu.ac.kr (S.Y.); ms1014@snu.ac.kr (M.S.P.); \\ jisun01144@gmail.com (J.S.K.) \\ 2 Forest Biodiversity Division, Korea National Arboretum, Pocheon-si 11186, Korea; changsun84@korea.kr \\ * Correspondence: ywlim@snu.ac.kr; Tel.: +82-2-880-6708
}

check for updates

Citation: Cho, Y.; Yoo, S.; Park, M.S.; Kim, J.S.; Kim, C.S.; Lim, Y.W. Ectomycorrhizal Fungi Associated with Pinus densiflora Seedlings under Flooding Stress. Sustainability 2021,

13, 4367. https://doi.org/ $10.3390 /$ su13084367

Academic Editor: Michelle Serapiglia

Received: 26 February 2021

Accepted: 12 April 2021

Published: 14 April 2021

Publisher's Note: MDPI stays neutral with regard to jurisdictional claims in published maps and institutional affiliations.

Copyright: (c) 2021 by the authors. Licensee MDPI, Basel, Switzerland. This article is an open access article distributed under the terms and conditions of the Creative Commons Attribution (CC BY) license (https:/ / creativecommons.org/licenses/by/ $4.0 /)$.

\begin{abstract}
Flooding is an environmental stress for plants that not only limits aeration and nutrient acquisition, but also disturbs underground plant-associated fungal communities. Despite frequent flooding, red pine (Pinus densiflora) seedlings thrive in streamside environments. However, whether the compatible ectomycorrhizal fungi (EMF) of red pine are affected by natural flooding is unclear. As EMF are vital symbionts for the development of many trees and allow them to overcome various environmental stresses, in this study, the EMF species associated with red pine seedlings in a streamside environment in Korea were investigated after flooding. The EMF species in 47 seedlings collected from the streamside site were identified by observing their different morphotypes using internal transcribed spacer sequence analysis, and a total of 10 EMF species were identified. The EMF species diversity was lower than that in samples collected from a nearby forest analyzed as a control. The dominant EMF species of streamside seedlings included Amphinema spp., Rhizopogon luteolus, Suillus luteus, and Thelephora terrestris. This study could serve as a basis for investigating the mechanisms by which advantageous EMF aid plant development under flooding stress.
\end{abstract}

Keywords: ectomycorrhizal fungi; flooding stress; red pine seedling; streamside

\section{Introduction}

Ectomycorrhizal fungi (EMF) uptake nutrients and water through the extension of hyphae, which they exchange with host plants for carbon [1]. In addition to assisting with the acquisition of essential nutrients and water, EMF allow plants to tolerate various detrimental environmental factors, such as droughts, flooding, and high heavy metal, salt, and organic pollutant concentrations [2-7]. The effects of EMF on plants under the context of climate change have recently been highlighted, and many studies have focused on characterizing the EMF-plant response to droughts [8-10]. However, little research has been conducted on EMF under flooding stress. Previous studies on ectomycorrhizal plants inhabiting regions that naturally flood reported that ectomycorrhizal formation is uncommon or infrequent $[6,11]$. However, some woody plants have been reported to form ectomycorrhizae when submerged in water, including Populus sp. and Salix sp. [12,13], and Pinus sylvestris [14].

Red pine (Pinus densiflora S. et Z.) is the predominant tree species in Korea, accounting for $28 \%$ of all trees (Forestry Management Survey, 2019). As well as forests, its seedlings readily grow on disturbed lands and wet habitats, such as streamside $[15,16]$. The ectomycorrhizae of red pine seedlings in forests and disturbed land in Korea have been studied $[17,18]$; however, the EMF composition of red pine seedlings in flooding regions remains unknown. In Korea, two typical floods occur in streamside regions annually. The first occurs consistently throughout early spring as the winter snow melts, and flash floods occur during the late-summer rainy season. Consequently, red pine seedlings and EMF in streamside habitats are affected by floods and frequent stream water inundation. 
This study aimed to elucidate the EMF species associated with red pine seedlings in a streamside environment in Korea immediately after large floods and compare them to those of the red pine seedlings in a nearby forest. The EMF diversity of seedlings from the streamside was lower than that of seedlings from the forest, and the dominant EMF species varied between sites. This study could serve as the basis for elucidating the mechanisms by which the ectomycorrhizae of water-resistant EMF species facilitate plant survival in wetlands.

\section{Materials and Methods}

\subsection{Seedling Collection}

In total, 47 Pinus densiflora seedlings were collected from a streamside habitat in Mount Seorak, Gangwon-do, Korea (38 $04^{\prime} 42.1^{\prime \prime}$ N 128 $19^{\prime} 18.6^{\prime \prime}$ E). The streamside habitat was bare, with minimum vegetation. The only tree species present was $P$. densiflora, and they were all young, age spanning approximately 1 to at most 5 . A total of 27 seedlings were collected in March 2020 (Str1), and the remaining 20 were collected in September 2020 (Str2), spring and late summer, respectively. The samples were collected from an area with frequent water deluge in addition to the regular floods. In 2020, two typical floods were detected by the downstream water level (http:/ / www.wamis.go.kr; accessed on 31 March 2021). The water level rose over early spring, as high as $276 \mathrm{~mm}$ with melting snow on February. On August, it rose up to $192 \mathrm{~mm}$ due to a flash flood. Aside from the floods, the water level consistently stayed around $175 \mathrm{~mm}$ over the year. A total of 15 Pinus densiflora seedlings were collected from a nearby forest $\left(38^{\circ} 05^{\prime} 02.0^{\prime \prime} \mathrm{N} 128^{\circ} 19^{\prime} 56.2^{\prime \prime} \mathrm{E}\right)$ as a control on March. They were growing at the forest edge of mature $P$. densiflora stands.

Most of the collected seedlings from both sites were one to two years old, and some were three to four years old. The uprooted seedlings were gently washed in the stream to remove excessive soil lumps and then placed in zipper bags with the roots submerged in stream water to prevent drying. The zipper bags were transported back to the laboratory in an icebox. For storage in the laboratory, the dirt on each seedling was rinsed off, and the seedling was then placed in a 50-mL Falcon tube filled with deionized water. The tubes were stored at $-20^{\circ} \mathrm{C}$ to preserve the ectomycorrhizal structures for further study.

\subsection{Morphotype Observation}

The roots of the pine seedlings were gently disentangled using sterile forceps in a sterile Petri dish; the root of all seedlings was small enough to be placed in a single Petri dish $(\varnothing=90 \mathrm{~mm})$. For easier observation, the lateral roots were cut from the taproot and placed on a black dissection Petri dish. The root tips with EMF were observed under a microscope (Nikon SMZ1500) at magnifications of 10 to $60 \times$. Photomicrography was then conducted using a NIS-Elements BR platform. For each seedling, root tips with variations in morphology [19] were detached and individually added to $40 \mu \mathrm{L}$ of $6 \%$ Chelex 100 (Bio-Rad, Richmond, CA, USA) in 0.2-mL tubes. Between one to six root tips of each morphotype were detached, and DNA was extracted from the isolated root tips for molecular identification.

\subsection{Molecular Identification of Ectomycorrhizae}

The root tips were placed in 0.2-mL tubes and ground using a micropestle. They were then boiled at $100{ }^{\circ} \mathrm{C}$ for $10 \mathrm{~min}$ and centrifuged for $10 \mathrm{~min}$ at $6000 \mathrm{rpm}$. Then, $1 \mu \mathrm{L}$ of the supernatant, which contained DNA, was diluted with $49 \mu \mathrm{L}$ of sterilized deionized water. The polymerase chain reaction (PCR) was then performed for the diluted DNA on a thermal cycler (Bio-Rad, Richmond, CA, USA) using a Maxime PCR PreMixStarTaq (Intron Biotechnology Inc., Seoul, Korea). The PCR proceeded at $95^{\circ} \mathrm{C}$ for $5 \mathrm{~min}$, followed by 35 cycles of $95{ }^{\circ} \mathrm{C}$ for $40 \mathrm{~s}, 55^{\circ} \mathrm{C}$ for $40 \mathrm{~s}$, and $72{ }^{\circ} \mathrm{C}$ for $1 \mathrm{~min}$, and then at $72{ }^{\circ} \mathrm{C}$ for $5 \mathrm{~min}$. NSI1 and NLB4 primers [20] were used to sequence the internal transcribed spacer (ITS) regions. For samples that were weakly amplified, nested PCR was performed using the ITS1F [21] and ITS4 [22] or ITS4B [21] primers at $95^{\circ} \mathrm{C}$ for $5 \mathrm{~min}$, followed by 35 cycles of 
$95{ }^{\circ} \mathrm{C}$ for $40 \mathrm{~s}, 58^{\circ} \mathrm{C}$ for $40 \mathrm{~s}$, and $72{ }^{\circ} \mathrm{C}$ for $1 \mathrm{~min}$, and then at $72{ }^{\circ} \mathrm{C}$ for $5 \mathrm{~min}$. The PCR products were then electrophoresed on $1 \%$ agarose gel and purified using an ExpinTM PCR Purification Kit (GeneAll Biotechnology, Seoul, Korea) following the manufacturer's instructions. All sequences were read with the PCR primers at Macrogen (Seoul, Korea) using an ABI Prism 3700 genetic analyzer (Life Technologies, Gaithersburg, MD, USA).

The obtained sequences were manually checked and edited, and molar identification was conducted in two steps. First, closely related species of each EMF were identified and gathered using the National Center for Biotechnology Information (NCBI) basic local alignment search tool (BLAST) results. Each EMF was then identified to the species level by phylogenetic analysis of the ITS region. Multiple alignments were conducted using multiple alignment fast Fourier-transform (MAFFT) version 7. Neighbor-joining (NJ) trees were then constructed in Molecular Evolutionary Genetics Analysis (MEGA) 7 using the Kimura 2-parameter model with 1000 bootstraps [23]. All sequences used in this study have been deposited in GenBank (Table 1).

Table 1. Ectomycorrhizal fungi species associated with red pine seedlings from the forest and streamside sites. Str1 and Str2 represent the seedlings collected from the streamside in March and September, respectively. GenBank accession numbers for the ITS region and the best sequence match from BLAST with similarity are also shown.

\begin{tabular}{|c|c|c|c|c|c|c|}
\hline \multirow{2}{*}{ EMF Species } & \multirow{2}{*}{ ITS Acc No. } & \multicolumn{3}{|c|}{ Collection Site } & \multicolumn{2}{|c|}{ Closest BLAST Match } \\
\hline & & Forest & Str1 & Str2 & Species (ITS Acc No.) & Similarity $(\%)$ \\
\hline Amphinema sp. 2 & MW546513 & $\checkmark$ & & & $\begin{array}{l}\text { Uncultured ectomycorrhizal } \\
\text { fungus (AB571491) }\end{array}$ & 100 \\
\hline Amphinema sp. 3 & MW546528 & $\checkmark$ & $\checkmark$ & $\checkmark$ & $\begin{array}{l}\text { Uncultured Amphinema } \\
\text { (LC013707) }\end{array}$ & 99.3 \\
\hline Amphinema sp. 4 & MW546524 & & $\checkmark$ & & $\begin{array}{l}\text { Uncultured Atheliaceae } \\
\text { (HM015485) }\end{array}$ & 99.5 \\
\hline Amphinema sp. 5 & MW546525 & & $\checkmark$ & $\checkmark$ & Amphinema sp. (MT678864) & 99.8 \\
\hline Astraeus hygrometricus & MW546516 & $\checkmark$ & & & $\begin{array}{l}\text { Astraeus hygrometricus } \\
\text { (LC001788) }\end{array}$ & 99.3 \\
\hline Atheliales sp. 1 & MW546511 & $\checkmark$ & & & Uncultured fungus (JQ975952) & 99.4 \\
\hline Cenococcum geophilum & MW546514 & $\checkmark$ & & & $\begin{array}{l}\text { Cenococcum geophilum } \\
\text { (LC523842) }\end{array}$ & 99.5 \\
\hline Coltriciella subglobosa & MW546517 & $\checkmark$ & & & Coltriciella sp. (KX159769) & 98.5 \\
\hline Helotiales sp. 1 & MW546512 & $\checkmark$ & & & $\begin{array}{l}\text { Uncultured Ascomycota } \\
\text { (FJ553907) }\end{array}$ & 99.6 \\
\hline Helotiales sp. 2 & MW546532 & & & $\checkmark$ & $\begin{array}{l}\text { Ectomycorrhizal root tip } \\
\text { (AF476977) }\end{array}$ & 97.9 \\
\hline Laccaria japonica & MW546523 & & $\checkmark$ & $\checkmark$ & Laccaria japonica (NR_158485) & 98.4 \\
\hline Laccaria parva & MW546529 & & $\checkmark$ & $\checkmark$ & Laccaria parva (MG519529) & 99.8 \\
\hline Rhizopogon luteolus & MW546531 & $\checkmark$ & $\checkmark$ & $\checkmark$ & Rhizopogon luteolus (AB972831) & 99.5 \\
\hline Sebacina sp. 1 & MW546520 & $\checkmark$ & & & $\begin{array}{l}\text { Uncultured Sebacinaceae } \\
\text { (FJ803936) }\end{array}$ & 98.2 \\
\hline Suillus bovinus & MW546527 & & $\checkmark$ & & Suillus bovinus (KJ415102) & 100 \\
\hline Suillus luteus & MW546526 & $\checkmark$ & $\checkmark$ & $\checkmark$ & Suillus luteus (KU059580) & 100 \\
\hline Thelephora terrestris & MW546530 & $\checkmark$ & $\checkmark$ & $\checkmark$ & Thelephora terrestris (AB634267) & 100 \\
\hline Tomentella ellisii & MW546510 & $\checkmark$ & & & Tomentella sp. (MK211713) & 97.7 \\
\hline Tomentella subtestacea & MW546519 & $\checkmark$ & & & $\begin{array}{l}\text { Tomentella subtestacea } \\
\text { (JQ711878) }\end{array}$ & 97.2 \\
\hline Tomentella sp. 1 & MW546518 & $\checkmark$ & & & Uncultured fungus (LC364196) & 98.6 \\
\hline Tomentella sp. 2 & MW546521 & $\checkmark$ & & & $\begin{array}{l}\text { Tomentella subtestacea } \\
\text { (JQ711878) }\end{array}$ & 96.1 \\
\hline Tomentella sp. 3 & MW546522 & $\checkmark$ & & & Tomentella sp. (KY686245) & 99.8 \\
\hline Tomentella sp. 4 & MW546515 & $\checkmark$ & & & Tomentella badia (JQ711856) & 95.7 \\
\hline
\end{tabular}




\section{Results}

\subsection{Morphological and Molecular Identification of EMF}

In total, the EMF species composition of 62 red pine seedlings was determined by morphotype sequencing. Between one to five different morphotypes were examined per seedling, and the sequenced ITS fragments mostly ranged from 500 to 800 base pairs. Some root tips had poor sequence quality and were excluded from the phylogenetic analysis. The 23 different EMF species were identified from the three sample groups. Of the 23 species, 11 were identified up to the species level, while the remaining 12 could not be identified due to insufficient public databases or inadequate taxonomic study of the genera. These species were numbered to distinguish between different congeneric species, and included species in Amphinema, Helotiales, and Tomentella (Figure 1 and Table 1).



Figure 1. EMF species associated with red pine seedlings from the forest and streamside sites arranged in a phylogenetic tree. ' $\mathrm{A}$ ' represents Ascomycota and ' $\mathrm{B}$ ' represents Basidiomycota. The colored bars indicate the percentage of each EMF in the number of seedlings from the forest (green) and streamside (Str1-yellow, Str2-blue) sites. The full length of a bar is set to $70 \%$. Bootstrap values $>95$ are shown.

The ectomycorrhizal morphologies of the EMF species were generally distinct from one another (Figure 2), and there were variations in color and size. Rootlets with ectomycorrhizal structures were distinct to the rootlets without any living EMF species, which were thinner, brown, and had a smoother surface, while dead ectomycorrhizal structures 
were dark in color with distinct wrinkles (Figure $2 \mathrm{~K}$ ). These structures were verified to have no living EMF species through molecular analysis, where no EMF DNA was detected by sequencing. Seedlings from the forest contained fewer dead ectomycorrhizae than those from the streamside region.
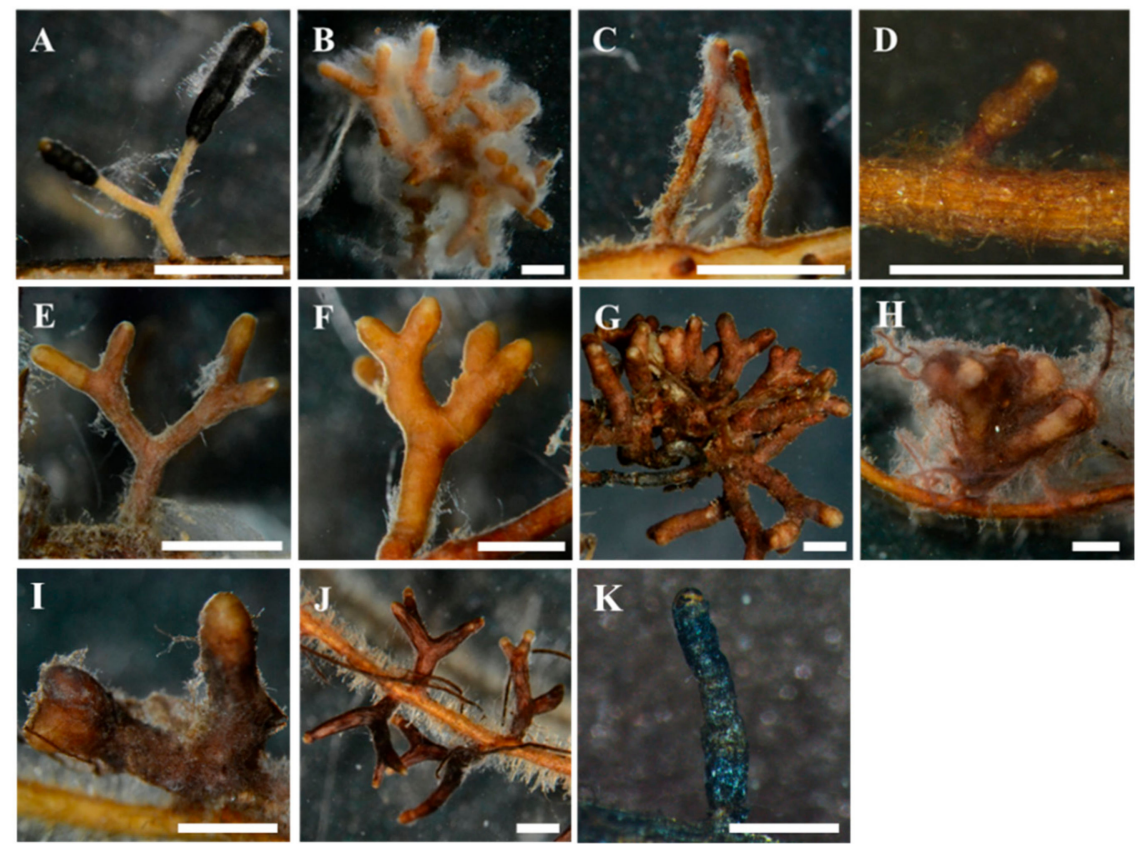

Figure 2. Morphotypes of ectomycorrhizal structures in red pine seedlings from the streamside site. (A): Amphinema sp. 3, (B): Amphinema sp. 4, (C): Amphinema sp. 5, (D): Helotiales sp. 2, (E): Laccaria japonica, (F): Laccaria parva, (G): Rhizopogon luteolus, (H): Suillus bovinus, (I): Suillus luteus, (J): Thelephora terrestris, $(\mathbf{K})$ : dead root tip. All scale bars are $1 \mathrm{~mm}$.

\subsection{EMF Species of Red Pine Seedlings}

Each seedling contained one to five EMF species, with most having two (seedling number, $n=31$ ); the average number of EMF species was 2.18. The number of EMF species in each seedling differed slightly between sampling occasions; average 2.53 for the forest samples, 2.26 for Str1, and 1.8 for Str2. In total, 17 different EMF species were observed among the 15 forest seedlings (Table 2), while 10 different EMF species were identified among the 47 streamside seedlings.

Among the species in the forest samples, Suillus luteus was observed in the greatest number of seedlings $(n=7)$, followed by Tomentella ellisii $(n=5)$, Cenococcum geophilum, and Rhizopogon luteolus ( $n=4$; Table 2$)$. R. luteolus and T. ellisii were also abundant in the ectomycorrhizal compositions of the individual seedlings (Table 2).

Among the species from the streamside samples, S. luteus and Thelephora terrestris were observed in the greatest number of seedlings $(n=20)$, followed by $R$. luteolus $(n=11)$. These species were also present in the forest samples, along with Amphinema sp. 3 (Figure 1 and Table 1). In total, nine different EMF species were identified in the 27 seedlings collected in March, with S. luteus ( $n=15)$, Amphinema sp. $4(n=13)$, and Laccaria parva $(n=10)$ occurring most frequently, and, when they were present within a seeding's ectomycorrhizal structure, L. japonica $(n=4)$ and T. terrestris $(n=7)$ were the dominant species (Table 3$)$. A total of eight different EMF species were identified in the 20 seedlings collected in September. T. terrestris $(n=13)$ was observed most frequently, followed by $R$. luteolus $(n=9)$, and S. luteus $(n=5$; Table 4). T. terrestris was also the dominant species in individual seedlings when present. Notably, Laccaria species were identified in the streamside seedlings and not observed in the forest seedlings, while C. geophilum and Tomentella spp. were present in the forest seedlings but not in the streamside seedlings. 
Table 2. EMF in individual red pine seedlings from the forest site. Filled circles indicate the most abundant EMF morphotype observed per seedling.

\begin{tabular}{|c|c|c|c|c|c|c|c|c|c|c|c|c|c|c|c|c|}
\hline \multirow{2}{*}{ EMF Species } & \multicolumn{15}{|c|}{ Forest Seedlings } & \multirow{2}{*}{ Sum } \\
\hline & 1 & 2 & 3 & 4 & 5 & 6 & 7 & 8 & 9 & 10 & 11 & 12 & 13 & 14 & 15 & \\
\hline Amphinema sp. 2 & 0 & & & & & & & & & & & & & & & 1 \\
\hline Amphinema sp. 3 & & & $\bullet$ & & & & & & & & & & & & & 1 \\
\hline Astraeus hygrometricus & & & & & & & & & 0 & & & & & & & 1 \\
\hline Atheliales sp. 1 & & - & 0 & 0 & & & & & & & & & & & & 3 \\
\hline Cепососсит geophilum & & & & & 0 & 0 & 0 & & 0 & & & & & & & 4 \\
\hline Coltriciella subglobosa & & & & & & & & & & 0 & & & & & & 1 \\
\hline Helotiales sp. 1 & & & & & & & & & & & $\bullet$ & $\bullet$ & & & & 2 \\
\hline Rhizopogon luteolus & 0 & & O & $\bullet$ & & & & & $\bullet$ & & & & & & & 4 \\
\hline Sebacina sp. 1 & & & & & & & & & & & & & & - & & 1 \\
\hline Suillus luteus & 0 & 0 & 0 & 0 & & & 0 & 0 & & & & 0 & & & & 7 \\
\hline Thelephora terrestris & - & & 0 & & & & & & & - & & & & & & 3 \\
\hline Tomentella ellisii & & & & & $\bullet$ & $\bullet$ & $\bullet$ & $\bullet$ & & & & 0 & & & & 5 \\
\hline Tomentella subtestacea & & & & & & & & & & & & & $\bullet$ & & & 1 \\
\hline Tomentella sp. 1 & & & & & & & & & & 0 & & & & & & 1 \\
\hline Tomentella sp. 2 & & & & & & & & & & & & & & & $\bullet$ & 1 \\
\hline Tomentella sp. 3 & & & & & & & & & & & & & & & O & 1 \\
\hline Tomentella sp. 4 & & & & & & & & & & & $\bigcirc$ & & & & & 1 \\
\hline Sum & 4 & 2 & 5 & 3 & 2 & 2 & 3 & 2 & 3 & 3 & 2 & 3 & 1 & 1 & 2 & \\
\hline
\end{tabular}

Table 3. EMF in individual red pine seedlings collected from the streamside site during March. Filled circles indicate the most abundant EMF morphotype observed per seedling.

\begin{tabular}{|c|c|c|c|c|c|c|c|c|c|c|c|c|c|c|c|c|c|c|c|c|c|c|c|c|c|c|c|c|}
\hline \multirow{2}{*}{ EMF Species } & \multicolumn{27}{|c|}{ Str1 Seedlings } & \multirow{2}{*}{ Sum } \\
\hline & 1 & 2 & 3 & 4 & 5 & 6 & 7 & 8 & 9 & 10 & 11 & 12 & 13 & 14 & 15 & 16 & 17 & 18 & 19 & 20 & 21 & 22 & 23 & 24 & 25 & 26 & 27 & \\
\hline Amphinema sp. 3 & & & & & & & & & & & 0 & 0 & & $\bullet$ & & & & & & & & & & & & & & 3 \\
\hline Amphinema sp. 4 & - & 0 & 0 & & 0 & & 0 & & - & 0 & - & & & 0 & & & & 0 & & & & 0 & & 0 & & - & & 13 \\
\hline Amphinema sp. 5 & & & $\bullet$ & & & & & & & & & 0 & & 0 & & & & & & & & $\bullet$ & & $\bullet$ & & & & 5 \\
\hline Laccaria japonica & & & & - & & & & & & & & & & & & & & & & & - & & & & - & & • & 4 \\
\hline Laccaria parva & & $\bullet$ & & 0 & & $\bullet$ & $\bullet$ & $\bullet$ & & & 0 & & & & $\bullet$ & & $\bullet$ & 0 & & & & & & & & & 0 & 10 \\
\hline $\begin{array}{l}\text { Rhizopogon } \\
\text { luteolus }\end{array}$ & & & & & & & & & & & & & & & $\bigcirc$ & & & & & & & & & $\bigcirc$ & & & & 2 \\
\hline Suillus bovinus & & & & & & & & & & & & 0 & & 0 & & & & & & & & & & & & & & 2 \\
\hline Suillus luteus & & & & 0 & $\bullet$ & 0 & ○ & 0 & O & 0 & 0 & & $\bullet$ & & & $\bullet$ & & $\bullet$ & 0 & 0 & 0 & 0 & & & & & & 15 \\
\hline $\begin{array}{l}\text { Thelephora } \\
\text { terrestris }\end{array}$ & & & & & & & & & & $\bullet$ & & - & & & & 0 & 0 & & • & • & & & $\bullet$ & & & & & 7 \\
\hline Sum & 1 & 2 & 2 & 3 & 2 & 2 & 3 & 2 & 2 & 3 & 4 & 4 & 1 & 4 & 2 & 2 & 2 & 3 & 2 & 2 & 2 & 3 & 1 & 3 & 1 & 1 & 2 & \\
\hline
\end{tabular}

Table 4. EMF in individual red pine seedlings collected from the streamside site during September. Filled circles indicate the most abundant EMF morphotype observed per seedling.

\begin{tabular}{|c|c|c|c|c|c|c|c|c|c|c|c|c|c|c|c|c|c|c|c|c|c|}
\hline \multirow{2}{*}{ EMF Species } & \multicolumn{20}{|c|}{ Str2 Seedlings } & \multirow{2}{*}{ Sum } \\
\hline & 1 & 2 & 3 & 4 & 5 & 6 & 7 & 8 & 9 & 10 & 11 & 12 & 13 & 14 & 15 & 16 & 17 & 18 & 19 & 20 & \\
\hline Amphinema sp. 3 & & & & & & & & & $\bullet$ & & & & & & & & & & & & 1 \\
\hline Amphinema sp. 5 & & & & & - & & & & & & & & & & & & & & & & 1 \\
\hline Laccaria japonica & & & & & & & & & & & & & $\bullet$ & & 0 & & & & & & 2 \\
\hline Laccaria parva & & & & & & & & & & & & & & & & & & & & - & 1 \\
\hline Helotiales sp. 2 & & & & 0 & & & & & & & & $\bullet$ & 0 & & & & & & & 0 & 4 \\
\hline Rhizopogon luteolus & 0 & 0 & - & & & & - & & & 0 & & & & 0 & & $\bullet$ & & & $\bullet$ & 0 & 9 \\
\hline Suillus luteus & - & & 0 & & 0 & & & & 0 & & - & & & & & & & & & & 5 \\
\hline Thelephora terrestris & & $\bullet$ & O & $\bullet$ & & $\bullet$ & & $\bullet$ & & $\bullet$ & 0 & $\bigcirc$ & & $\bullet$ & $\bullet$ & 0 & $\bullet$ & $\bullet$ & & & 13 \\
\hline Sum & 2 & 2 & 3 & 2 & 2 & 1 & 1 & 1 & 2 & 2 & 2 & 2 & 2 & 2 & 2 & 2 & 1 & 1 & 1 & 3 & \\
\hline
\end{tabular}

\section{Discussion}

In total, 23 EMF species were identified in seedlings from the streamside habitat and the nearby forest (three ascomycetes and 20 basidiomycetes), all of which were similar 
to the commonly reported EMF species of red pine seedlings in forests and disturbed areas $[17,18,24-26]$. The EMF diversity of the red pine seedlings from the streamside region was lower than that of the seedlings from the forest, although more streamside seedlings were assessed. The EMF composition also varied between the forest and streamside seedlings, with more black and dead root tips observed in the streamside samples. These results indicate that the pine seedlings were affected by the frequent flow of water. The structure of the root systems of pine species change when they are periodically submerged by floods of moving water, with old root tips turning dark in color or dying, and the emergence of new root tips becoming limited [27]. Frequent flooding also limits aeration in the subsoil layer [28], which negatively affects the mycorrhizal biomass and diversity [29].

Of the 10 EMF species observed in the streamside seedlings, Amphinema spp., L. parva, $R$. luteolus, S. luteus, and T. terrestris were dominant, although there were some differences in the species compositions of the samples collected in March and September. L. laccata and T. terrestris are insensitive to flooding, while Suillus bovinus and Suillus flavidus are highly sensitive [13]. Our results also indicate that Laccaria spp. and T. terrestris are resistant to flooding, while the resistance of Suillus spp. are variable. S. bovinus was not frequently detected in the streamside samples, whereas S. luteus was abundant, suggesting that S. luteus is less sensitive than other Suillus species. Amphinema spp., Laccaria spp., and S. bovinus were most abundant in spring, while Helotiales sp. 2 and R. luteolus were mostly found in late summer and S. luteus and T. terrestris were present in both seasons. The EMF found in September could have tolerated the short flash flooding period, as flash floods are sporadic and do not last long. Therefore, the EMF composition in September resembled that of the seedlings found on disturbed lands in Korea [18].

A total of three different Amphinema species were commonly associated with the roots of streamside pine seedlings. As Amphinema species were only identified through morphotyping and ITS sequencing, they could not be described at the species level. There are few studies done on the taxonomy or phylogeny of the genera in Atheliaceae, despite their common occurrence and abundance in pine ectomycorrhizae; many studies documented species within this family as Atheliaceae spp. or Amphinema sp. [30-32]. During the collection of the streamside seedlings, the white mycelium structure was clearly visible underground, even to the unaided eye. This structure was identified as Amphinema sp. 3 by sequencing the ITS region of the mycelia. Amphinema species exhibited relatively higher enzyme activities for cellulose and hemicellulose degradation, suggesting that they also function as saprotrophs [33] and can breakdown organic products on their own to provide nutrients to the hosts. Amphinema byssoides plays an important role in the survival and establishment of outplanted Picea abies seedlings [34]. Similarly, Amphinema species may be advantageous for the tolerance and growth of red pine seedlings after soil is washed away by flooding, which displaces the nutrients and the existing microorganisms.

In total, two Laccaria species were identified in the roots of streamside red pine seedlings; however, they were not observed in the forest seedlings. Laccaria species flourish as early successional EMF in intact forests [35]. Laccaria laccata, an EMF of Pinus sylvestris seedlings, is less sensitive to flooding [13], which supports our finding that Laccaria species are tolerant to frequent inundation and flooding. The absence of $C$. geophilum, a successful EMF of red pine seedlings [36], in the streamside samples was unexpected as it was observed in $26 \%$ of the forest seedlings in this study (Table 2), and it is hydrophilic [37]. However, C. geophilum is sensitive to the host type and precise water potential in flooding areas [12], which could explain its absence from the roots of streamside seedlings. Furthermore, C. geophilum is assumed to exert a negative impact on the growth and colonization of L. japonica at root tips [38]; therefore, its absence could have provided an opportunity for L. japonica to colonize the streamside red pine seedlings. T. terrestris, which is also common in red pine seedlings [25], was abundant in both the forest and streamside seedlings, and is also hydrophilic [37]. Unlike C. geophilum, T. terrestris is relatively insensitive to flooding [13]. This was also corroborated here, as T. terrestris was observed in the streamside seedlings during both seasons. Previous work reported that T. terrestris does not prefer 
aeration [37], which may have allowed it to remain viable when soil became anaerobic due to flooding.

To some extent, the difference of EMF composition between the two habitats could be explained by the EMF exploration type. Given that some species were not identified fully to species level, assessing the exploration type of all was not possible. However, considering the general exploration type of each genera, it was shown that contact exploration type species, such as Cenococcum geophilum and Tomentella spp. [39], were less associated with the seedlings collected from the streamside habitat than the seedlings from the forest. Contact type EMF were favored when the water content in air and soil dropped with an increase in temperature, while contact-medium type EMF reduced in abundance and mediumlong type EMF had no significant change [40]. Overhydration of the soil in flooding habitat contradicts the condition that contact type species favor, explaining their absence. The exploration types of species present on the streamside were mostly medium-distant (Amphinema spp., Laccaria spp., and Thelephora terrestris [39]) and long (Rhizopogon luteous and Suillus spp. [39]), suggesting that these exploration types are relatively adaptable to a wide range of habitat or abiotic factors.

The small number of samples collected from a restricted study area in this work could introduce bias if the EMF composition of streamside red pine seedlings is generalized based on this work. Continuously monitoring the EMF composition or investigating other sites may reveal more EMF species in red pine seedlings affected by flooding, and persistently analyzing seedlings affected by floods may uncover EMF species that are tolerant or completely resistant to flooding stress. This study could serve as a basis for future research on EMF mechanisms that combat environmental stress in wetlands.

Author Contributions: Conceptualization, Y.C. and Y.W.L.; methodology, Y.C. and S.Y.; validation, Y.C. and S.Y.; investigation, Y.C. and S.Y.; writing-original draft preparation, Y.C.; writing-review and editing, Y.C., M.S.P., J.S.K., and Y.W.L.; visualization, Y.C., S.Y., and Y.W.L.; supervision, Y.W.L.; funding acquisition, C.S.K. and Y.W.L. All authors have read and agreed to the published version of the manuscript.

Funding: This study was supported by the Korea National Arboretum (grant number KNA1-1-25, 19-2).

Institutional Review Board Statement: Not applicable.

Informed Consent Statement: Not applicable.

Data Availability Statement: Not applicable.

Acknowledgments: Not applicable.

Conflicts of Interest: The authors declare no conflict of interest. The sponsors had no role in the design, execution, interpretation, or writing of the study.

\section{References}

1. Smith, S.E.; Read, D.J. Mycorrhizal Symbiosis; Academic Press: New York, NY, USA, 2010; ISBN 978-0-12-370526-6.

2. Parke, J.L.; Linderman, R.G.; Black, C.H. The role of ectomycorrhizas in drought tolerance of Douglas-fir seedlings. New Phytol. 1983, 95, 83-95. [CrossRef]

3. Denny, H.J.; Wilkins, D.A. Zinc tolerance in Betula spp. IV. The mechanism of ectomycorrhizal amelioration of zinc toxicity. New Phytol. 1987, 106, 545-553.

4. Tam, P.C.F. Heavy metal tolerance by ectomycorrhizal fungi and metal amelioration by Pisolithus tinctorius. Mycorrhiza 1995, 5, 181-187. [CrossRef]

5. Meharg, A.A.; Cairney, J.W. Ectomycorrhizas-Extending the capabilities of rhizosphere remediation? Soil Biol. Biochem. 2000, 32, 1475-1484. [CrossRef]

6. Sumorok, B.; Kosiński, K.; Michalska-Hejduk, D.; Kiedrzyńska, E. Distribution of ectomycorrhizal fungi in periodically inundated plant communities on the Pilica river floodplain. Ecohydrol. Hydrobiol. 2008, 8, 401-410. [CrossRef]

7. Guerrero-Galán, C.; Calvo-Polanco, M.; Zimmermann, S.D. Ectomycorrhizal symbiosis helps plants to challenge salt stress conditions. Mycorrhiza 2019, 29, 291-301. [CrossRef] [PubMed]

8. Kilpeläinen, J.; Barbero-López, A.; Vestberg, M.; Heiskanen, J.; Lehto, T. Does severe soil drought have after-effects on arbuscular and ectomycorrhizal root colonisation and plant nutrition? Plant Soil 2017, 418, 377-386. [CrossRef] 
9. Sebastiana, M.; Duarte, B.; Monteiro, F.; Malhó, R.; Caçador, I.; Matos, A.R. The leaf lipid composition of ectomycorrhizal oak plants shows a drought-tolerance signature. Plant Physiol. Biochem. 2019, 144, 157-165. [CrossRef]

10. Gehring, C.; Sevanto, S.; Patterson, A.; Ulrich, D.E.M.; Kuske, C. Ectomycorrhizal and dark septate fungal associations of pinyon pine are differentially affected by experimental drought and warming. Front. Plant Sci. 2020, 11, 1570. [CrossRef]

11. Theodorou, C. Soil moisture and the mycorrhizal association of Pinus radiata D. don. Soil Biol. Biochem. 1978, 10, 33-37. [CrossRef]

12. Lodge, D.J. The influence of soil moisture and flooding on formation of VA-endo-and ectomycorrhizae in Populus and Salix. Plant Soil 1989, 117, 243-253. [CrossRef]

13. Hashimoto, Y.; Higuchi, R. Ectomycorrhizal and arbuscular mycorrhizal colonization of two species of floodplain willows. Mycoscience 2003, 44, 339-343. [CrossRef]

14. Stenström, E. The effects of flooding on the formation of ectomycorrhizae in Pinus sylvestris seedlings. Plant Soil 1991, 131, 247-250. [CrossRef]

15. Nakaji, T.; Fukami, M.; Dokiya, Y.; Izuta, T. Effects of high nitrogen load on growth, photosynthesis and nutrient status of Cryptomeria japonica and Pinus densiflora seedlings. Trees 2001, 15, 453-461. [CrossRef]

16. Norisada, M.; Motoshige, T.; Kojima, K.; Tange, T. Effects of phosphate supply and elevated $\mathrm{CO}_{2}$ on root acid phosphatase activity in Pinus densiflora seedlings. J. Soil Sci. Plant Nutr. 2006, 169, 274-279. [CrossRef]

17. Sim, M.Y.; Eom, A.H. Diversity of ectomycorrhizal fungi of Pinus densiflora Siebold et Zucc. Seedlings in a disturbed forest on Mt. Songni. J. Ecol. Environ. 2009, 32, 13-18. [CrossRef]

18. Lee, E.H.; Eom, A.H. Ectomycorrhizal fungal communities of red pine (Pinus densiflora) seedlings in disturbed sites and undisturbed old forest sites. Mycobiology 2013, 41, 77-81. [CrossRef]

19. Agerer, R. Characterization of ectomycorrhiza. Methods Microbiol. 1991, 23, 25-73.

20. Martin, K.J.; Rygiewicz, P.T. Fungal-specific PCR primers developed for analysis of the ITS region of environmental DNA extracts. BMC Microbiol. 2005, 5, 28. [CrossRef]

21. Gardes, M.; Bruns, T.D. ITS primers with enhanced specificity for basidiomycetes-application to the identification of mycorrhizae and rusts. Mol. Ecol. 1993, 2, 113-118. [CrossRef]

22. White, T.J.; Bruns, T.; Lee, S.; Taylor, J. Amplification and direct sequencing of fungal ribosomal RNA genes for phylogenetics. In PCR Protocols: A Guide to Methods and Applications; Academic Press: Cambridge, MA, USA, 1990; pp. 315-322. ISBN 978-012-372181-5.

23. Kumar, S.; Stecher, G.; Tamura, K. MEGA7: Molecular evolutionary genetics analysis version 7.0 for bigger datasets. Mol. Biol. Evol. 2016, 33, 1870-1874. [CrossRef] [PubMed]

24. Satomura, T.; Nakatsubo, T.; Horikoshi, T. Estimation of the biomass of fine roots and mycorrhizal fungi: A case study in a Japanese red pine (Pinus densiflora) stand. J. For. Res. 2003, 8, 221-225. [CrossRef]

25. Obase, K.; Cha, J.Y.; Lee, S.Y.; Lee, J.K.; Chun, K.W. Ectomycorrhizal fungal community associated with naturally regenerating Pinus densiflora Sieb. et Zucc. seedlings on exposed granite slopes along woodland paths. J. For. Res. 2012, 17, 388-392. [CrossRef]

26. Obase, K. Extending the hyphal area of the ectomycorrhizal fungus Laccaria parva co-cultured with ectomycorrhizosphere bacteria on nutrient agar plate. Mycoscience 2019, 60, 95-101. [CrossRef]

27. Hunt, F.M. Effects of flooded soil on growth of pine seedlings. Plant Physiol. 1951, 26, 363-368. [CrossRef]

28. Ponnamperuma, F.N. Effects of flooding on soils. In Flooding and Plant Growth; Kozlowski, T.T., Ed.; Academic Press: Cambridge, MA, USA, 1984; pp. 9-45. ISBN 978-0-12-424120-6.

29. Unger, I.M.; Kennedy, A.C.; Muzika, R.M. Flooding effects on soil microbial communities. Appl. Soil Ecol. 2009, 42, 1-8. [CrossRef]

30. Wang, Q.; Guo, L.D. Ectomycorrhizal community composition of Pinus tabulaeformis assessed by ITS-RFLP and ITS sequences. Botany 2010, 88, 590-595. [CrossRef]

31. Martin-Sanchez, P.M.; Sáiz-Jiménez, C. Contribution of culture-independent methods to cave aerobiology: The case of Lascaux cave. In The Conservation of Subterranean Cultural Heritage; Saiz-Jimenez, C., Ed.; Taylor \& Francis Group: London, UK, 2014; pp. 215-222. ISBN 978-1-315-73997-7.

32. Wen, Z.; Murata, M.; Xu, Z.; Chen, Y.; Nara, K. Ectomycorrhizal fungal communities on the endangered Chinese Douglas-fir (Pseudotsuga sinensis) indicating regional fungal sharing overrides host conservatism across geographical regions. Plant Soil 2015, 387, 189-199. [CrossRef]

33. Phillips, L.A.; Ward, V.; Jones, M.D. Ectomycorrhizal fungi contribute to soil organic matter cycling in sub-boreal forests. ISME J. 2014, 8, 699-713. [CrossRef]

34. Menkis, A.; Bakys, R.; Lygis, V.; Vasaitis, R. Mycorrhization, establishment and growth of outplanted Picea abies seedlings produced under different cultivation systems. Silva Fenn. 2011, 45, 283-289. [CrossRef]

35. Dickie, I.A.; Richardson, S.J.; Wiser, S.K. Ectomycorrhizal fungal communities and soil chemistry in harvested and unharvested temperate Nothofagus rainforests. Can. J. For. Res. 2009, 39, 1069-1079. [CrossRef]

36. Ma, D.; Yang, G.; Mu, L. Morphological and molecular analyses of ectomycorrhizal diversity in Pinus densiflora seedlings. Symbiosis 2010, 51, 233-238. [CrossRef]

37. Unestam, T. Water repellency, mat formation, and leaf-stimulated growth of some ectomycorrhizal fungi. Mycorrhiza 1991, 1, 13-20. [CrossRef] 
38. Zhang, S.; Vaario, L.M.; Xia, Y.; Matsushita, N.; Geng, Q.; Tsuruta, M.; Kurokochi, H.; Lian, C. The effects of co-colonising ectomycorrhizal fungi on mycorrhizal colonisation and sporocarp formation in Laccaria japonica colonising seedlings of Pinus densiflora. Mycorrhiza 2019, 29, 207-218. [CrossRef]

39. Agerer, R. Exploration types of ectomycorrhizae. Mycorrhiza 2001, 11, 107-114. [CrossRef]

40. Fernandez, C.W.; Nguyen, N.H.; Stefanski, A.; Han, Y.; Hobbie, S.E.; Montgomery, R.A.; Reich, P.B.; Kennedy, P.G. Ectomycorrhizal fungal response to warming is linked to poor host performance at the boreal-temperate ecotone. Glob. Chang. Biol. 2017, 23, 1598-1609. [CrossRef] 